\title{
Claudin-1 expression is induced by tumor necrosis factor- $\alpha$ in human pancreatic cancer cells
}

\author{
JUN KONDO ${ }^{1,2}$, FUYUKI SATO ${ }^{1}$, TOMOMI KUSUMI ${ }^{1}$, YANG LIU ${ }^{1}$, \\ OHASHI MOTONARI ${ }^{1}$, TATSUSUKE SATO ${ }^{2}$ and HIROSHI KIJIMA ${ }^{1}$ \\ ${ }^{1}$ Department of Pathology and Bioscience, Hirosaki University Graduate School of Medicine, \\ Hirosaki 036-8562; ${ }^{2}$ Department of Pathologic Analysis Division of Medical Life Sciences, \\ Hirosaki University Graduate School of Health Sciences, Hirosaki 036-8564, Japan
}

Received June 2, 2008; Accepted July 30, 2008

DOI: 10.3892/ijmm_00000067

\begin{abstract}
Claudin-1 is a membrane protein with four transmembrane domains, that is exclusively localized at cellular tight junctions. Recent studies have reported that claudin-1 plays an important role in cancer invasion and metastasis. However, the significance of claudin-1 in pancreatic cancer is still unknown. In the present study, we investigated the role of claudin-1 expression in pancreatic cancer growth using the PANC-1 human pancreatic cancer cell line. Treatment with tumor necrosis factor- $\alpha$ (TNF- $\alpha)$, an inflammatory cytokine, resulted in increased detection of $89 \mathrm{kDa}$ products of poly(ADP-ribose) polymerase (PARP), a marker of apoptosis, and decreased PANC-1 cell proliferation by $23 \%$. Expression of claudin-1 was up-regulated by TNF- $\alpha$ in a concentrationdependent manner in PANC-1 cells. PANC-1 cells treated with TNF- $\alpha$ and siRNA against claudin- 1 showed a $15 \%$ increase in proliferation; i.e. the cells transfected with siRNA against claudin- 1 showed resistance to TNF- $\alpha$-induced apoptosis. These results suggest that claudin-1 expression is responsible for TNF- $\alpha$-dependent growth signals and the proliferation of pancreatic cancer cells.
\end{abstract}

\section{Introduction}

Tight junctions of cells serve as a barrier that prevents solutes and water from passing through the paracellular pathway, and as a fence between the apical and basolateral plasma membranes in epithelial cells. Tight junctions consist of transmembrane proteins such as claudins and many peripheral membrane

Correspondence to: Dr Fuyuki Sato, Department of Pathology and Bioscience, Hirosaki University Graduate School of Medicine, 5 Zaifu-cho, Hirosaki 036-8562, Japan

E-mail: fsato@cc.hirosaki-u.ac.jp

Abbreviations: TNF- $\alpha$, tumor necrosis factor- $\alpha$; PARP, poly (ADP-ribose) polymerase; IFN- $\gamma$, interferon- $\gamma$

Key words: claudin-1, tumor necrosis factor- $\alpha$, PANC-1, poly (ADP-ribose) polymerase proteins $(1,2)$. Claudins play crucial roles in the formation and maintenance of the tight junctions. Claudins were first discovered in 1998, and the claudins family consists of at least 24 newly discovered members, the expression of which depend on cell type and tissue $(2,3)$. Claudins are connected with the actin cytoskeleton and participate in intracellular signaling $(4,5)$. In this context, the downward or upward regulation of claudins may have a role in cancer development. Alterations of claudin expression have been noted in several tumor types such as colorectal, ovarian, and breast cancer, suggesting their involvement in carcinogenesis (6-11).

Pancreatic cancer is one of the most lethal cancers, with a 3 -year survival rate of $\leq 10 \%$ (12-17). Factors responsible for this poor prognosis include: a) difficulty in early diagnosis due to anatomical location and lack of early symptoms; b) limitations of conventional cancer therapies including surgery, chemotherapy, radiation therapy, and immune therapy; c) rapid spreading of tumors to the surrounding organs, causing obstructive jaundice; and d) frequent incidence of metastasis even from a small primary tumor $\leq 2 \mathrm{~cm}$ in diameter. Pancreatic cancer ranks fifth as a cause of cancer-related mortality in the USA and Japan. Modulation of the aggressive cell proliferation of pancreatic cancer is one of the most significant issues in modern medicine $(18,19)$.

Tumor necrosis factor- $\alpha(\mathrm{TNF}-\alpha)$ is a cytokine that induces a diverse range of biological responses, including the induction of apoptosis and anti-proliferative effects in various cells $(20,21)$. Interleukin (IL)-1, IL-6, and TNF- $\alpha$ are produced after cancer treatments such as surgical intervention and nonspecific immunotherapy (22). These cytokines produced either locally or systematically may directly affect the growth and the metastasis of tumor cells. The effects of TNF- $\alpha$ on the expression of tight junction proteins are still unknown.

In this study, we examined the expression of claudin-1 in PANC-1 human pancreatic cancer cells treated with TNF- $\alpha$ and investigated the functions of claudins in the apoptosis of cancer cells.

\section{Materials and methods}

Cell culture and treatment. PANC-1 human pancreatic cancer cells were obtained from the American Type Culture 
Collection (ATCC, Manassas, VA, USA). Cells were cultured in RPMI 1640 medium (Gibco, Breda, The Netherlands) and supplemented with $10 \%$ fetal bovine serum. They were cultured at $37^{\circ} \mathrm{C}$ in a humidified atmosphere of $95 \%$ air and $5 \% \mathrm{CO}_{2}$. Cells were incubated with recombinant human TNF- $\alpha$ (R\&D systems, Minneapolis, MN, USA) and interferon- $\gamma$ $(\mathrm{IFN}-\gamma)(\mathrm{R} \& \mathrm{D}$ systems) at various concentrations and periods.

Reverse transcription-polymerase chain reaction (RT-PCR). Total RNA was isolated using an RNeasy RNA isolation kit (Qiagen, Hilden, Germany). First-strand cDNA was synthesized from $1 \mu \mathrm{g}$ of total RNA using Rever Tra Ace (Toyobo, Osaka, Japan). PCR was performed using an aliquot of firststrand cDNA as a template under standard conditions with Taq DNA polymerase (Takara, Shiga, Japan). The cDNAs for human claudin-1 and glyceraldehyde 3-phosphate dehydrogenase (GAPDH) were amplified for up to 25 cycles. The primers used were as follows: Claudin-1-F: 5'-CAGCTGT TGGGCTTCATTCTC-3', claudin-1-R: 5'-ATCACTCCC AGGAGGATGCC-3', GAPDH-F: 5'-CCACCCATGG CAAATTCCATGGCA-3' and GAPDH-R: 5'-AGACCA CCTGGTGCTCAGTGTAGC-3'. The predicted sizes of the amplified products for claudin-1 and GAPDH were 277 bp and $696 \mathrm{bp}$, respectively. The PCR products were separated on $1.5 \%(\mathrm{w} / \mathrm{v})$ agarose gels.

Short interference RNA (siRNA). Short interference RNA (siRNA) against claudin-1 was used for the knockdown of claudin-1 gene expression. The sequences for the siRNA against claudin-1 were as follows: sense 5'-r (GCAUGGUA UGGCAAUAGAA) d (TT)-3' and antisense 5'-r (UUCUAU UGCCAUACCAUGC) d (TG)-3'. The sequences for the negative control siRNA were as follows: sense 5'-r (UUCU CCGAACGUGUCACGU) d (TT)-3' and antisense 5'-r (ACGUGACACGUUCGGAGAA) d (TT)-3'. The siRNA was transfected into cells using Lipofectamine 2000 reagent (Invitrogen, Carlsbad, CA, USA). Transfection, cells were then incubated for $48 \mathrm{~h}$.

Western blot analysis. Cells were seeded at $5 \times 10^{4}$ cells per $35-\mathrm{mm}$ well and siRNA was transfected into cells using Lipofectamine 2000 reagent. The cells were incubated for $48 \mathrm{~h}$ and treated with TNF- $\alpha$, IFN- $\gamma$, or TNF- $\alpha /$ IFN- $\gamma$ combination (each $50 \mathrm{ng} / \mathrm{ml}$ ). Cells were then lysed using M-PER lysis buffer (Pierce, Rockford, IL, USA), and proteins were prepared for Western blot analysis. Protein concentrations were determined by BCA (bicinchoninic acid) assay. The lysates (20 $\mu \mathrm{g}$ protein) were subjected to SDS-PAGE, and proteins were transferred to PVDF membranes. The membranes were incubated with antibodies specific for claudin-1 $(1: 1,000)$ (Zymed, South San Francisco, CA, USA), claudin-4 $(1: 15,000)$ (Zymed), poly (ADP-ribose) polymerase (PARP, 1:1,000) (Cell Signaling Tech, Danvers, MA, USA) or actin (Sigma, St. Louis, MO, USA) followed by a horseradish peroxidaseconjugated secondary antibody. An ECL Plus Western Blotting Detection System (Amersham, Uppsala, Sweden) was used for detection.

MTS [3-(4,5-dimethylthiazol-2-yl)-5-(3-carboxymethoxyphenyl)2-(4-sulfophenyl)-2H-tetrazolium] assay. Cells were seeded

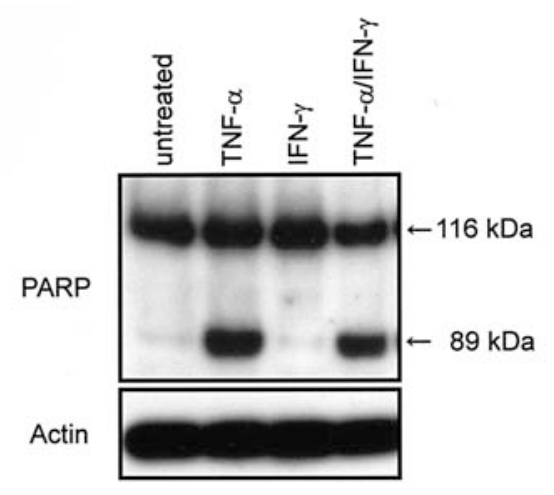

Figure 1. Detection of cleaved PARP in PANC-1 cells by Western blotting Cells were treated with TNF- $\alpha$, IFN- $\gamma$, or TNF- $\alpha /$ IFN- $\gamma$ combination (each $50 \mathrm{ng} / \mathrm{ml}$ ) for $24 \mathrm{~h}$. Untreated cells detected full-length PARP (116 kDa). TNF- $\alpha$ or TNF- $\alpha /$ IFN $-\gamma$ combination showed increased PARP cleavage $(89 \mathrm{kDa})$.

at $2.5 \times 10^{4}$ in 96 -well plates. Cells were transfected with siRNA against claudin-1. After 2 days, cells were treated with TNF- $\alpha(50 \mathrm{ng} / \mathrm{ml})$ and incubated for $24 \mathrm{~h}$. The cells were added (Cell Titer 96 AQuenous One Solution Reagent) (Promega Corporation, Madison, WI, USA) to each well, and were incubated at $37^{\circ} \mathrm{C}$ for an additional $1 \mathrm{~h}$. The absorbance $\left(\mathrm{OD}_{490} \mathrm{~nm}\right)$ was measured using a $96-$ well plate reader.

Statistics. Data were presented as a mean \pm SD. Statistical significance was determined by Student's t test. Comparisons with $\mathrm{p} \leq 0.05$ were considered statistically significant.

\section{Results}

Effects of TNF- $\alpha$ and IFN- $\gamma$ in PANC-1 cells. PANC-1 cells were seeded at $1 \times 10^{5}$ cells per $35-\mathrm{mm}$ well and treated with TNF- $\alpha$, IFN- $\gamma$, or TNF- $\alpha /$ IFN- $\gamma$ combination (each $50 \mathrm{ng} / \mathrm{ml}$ ). Cells were incubated for $24 \mathrm{~h}$ and cleaved PARP was examined using Western blot analysis (Fig. 1). PARP, an important indicator of apoptosis, is cleaved into $89 \mathrm{kDa}$ products by caspase-3. Untreated cells detected full-length PARP (116 kDa), but did not demonstrate cleaved PARP (89 kDa). PANC-1 cells treated with TNF- $\alpha$ or TNF- $\alpha /$ IFN- $\gamma$ combination demonstrated increased PARP cleavage $(89 \mathrm{kDa})$.

PANC-1 cells were seeded in 96-well plates, treated with TNF- $\alpha$, IFN- $\gamma$, or TNF- $\alpha / \mathrm{IFN}-\gamma$ combination $(50 \mathrm{ng} / \mathrm{ml})$, and incubated for $24 \mathrm{~h}$. MTS-assay demonstrated that the cells treated with TNF- $\alpha$ and TNF- $\alpha /$ IFN- $\gamma$ combination showed $23 \%(\mathrm{p}=0.000012)$ and $37 \%(\mathrm{p}=0.0000034)$ decrease in proliferation $(\mathrm{p} \leq 0.05)$, respectively compared to untreated control cells (Fig. 2). In contrast, PANC-1 cells treated with IFN- $\gamma$ showed an $11 \%$ decrease in proliferation. Therefore, TNF- $\alpha$ induced apoptosis in PANC- 1 cells.

Up-regulation of claudin-1 expression by TNF- $\alpha$ in PANC-1 cells. PANC-1 cells were treated with various concentrations of TNF- $\alpha$ for $24 \mathrm{~h}$, or $10 \mathrm{ng} / \mathrm{ml}$ of TNF- $\alpha$ treatment for 2,8 , and $24 \mathrm{~h}$. Gene expression of claudin-1 was evaluated by RTPCR analyses. The mRNA expression of claudin-1 was upregulated by TNF- $\alpha$ in a concentration-dependent manner (Fig. 3A) and claudin-1 mRNA expression was further 


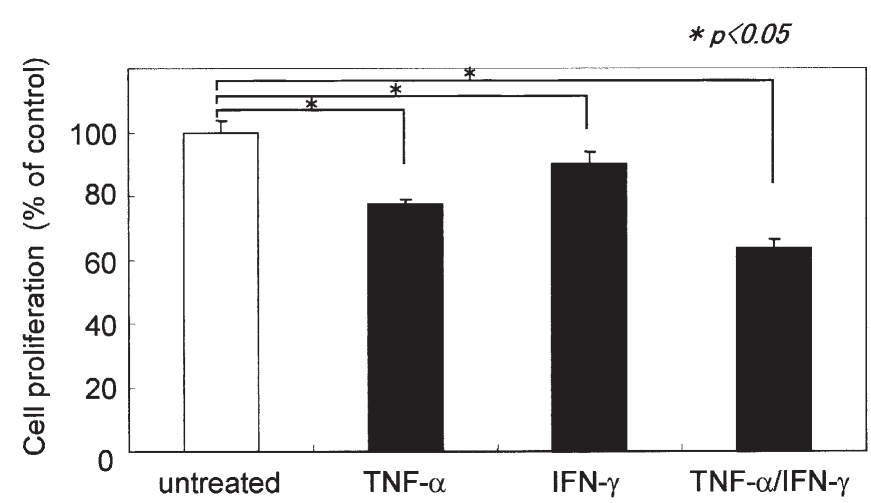

Figure 2. Proliferation of PANC-1 cells by MTS-assay. Cells were treated with TNF- $\alpha$, IFN- $\gamma$, or TNF- $\alpha /$ IFN- $\gamma$ combination (each $50 \mathrm{ng} / \mathrm{ml}$ ) for $24 \mathrm{~h}$. MTSassay demonstrated that the cells treated with TNF- $\alpha$ IFN- $\gamma$ or TNF- $\alpha /$ IFN- $\gamma$ combination showed 23,11 or $37 \%$ decrease in proliferation $(\mathrm{p} \leq 0.05)$, respectively compared with untreated control cells.

A

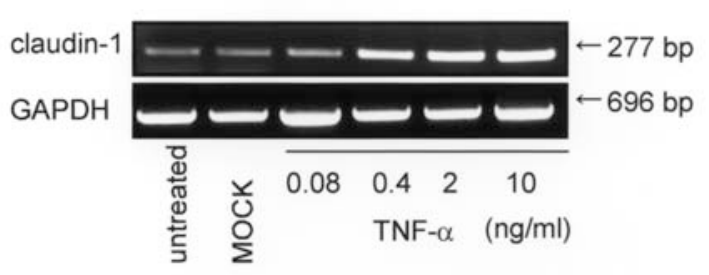

B

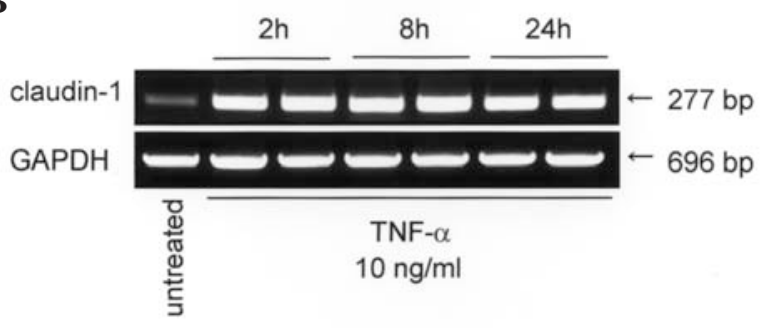

C

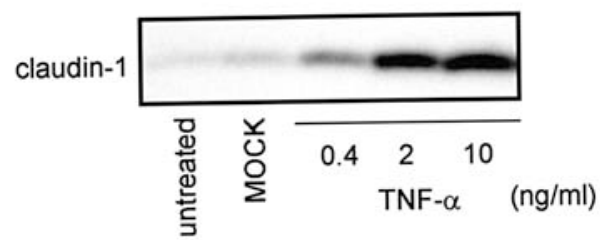

D

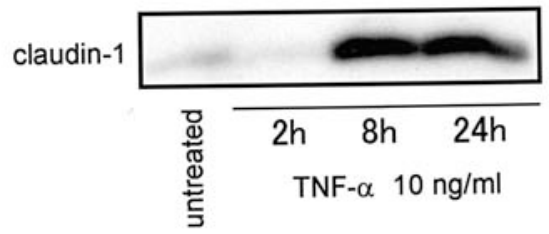

Figure 3. Expression of claudin-1 in PANC-1 cells. (A, RT-PCR) PANC-1 cells were treated with MOCK (buffer only) or $0.08,0.4,2$, and $10 \mathrm{ng} / \mathrm{ml}$ TNF- $\alpha$ for $24 \mathrm{~h}$. The mRNA expression of claudin- 1 was up-regulated by TNF- $\alpha$ in concentration-dependent manner. (B, RT-PCR) PANC-1 cells were treated with TNF- $\alpha(10 \mathrm{ng} / \mathrm{ml})$ for 2,8 , and $24 \mathrm{~h}$. Claudin-1 mRNA expression was increased by TNF- $\alpha$ treatment for 2,8 , and $24 \mathrm{~h}$. (C, Western blotting) PANC-1 cells were treated with MOCK or $0.4,2$, and $10 \mathrm{ng} / \mathrm{ml}$ TNF- $\alpha$ for $24 \mathrm{~h}$. Claudin-1 protein expression was up-regulated by TNF- $\alpha$ in a concentration-dependent manner. (D, Western blotting) PANC-1 cells were treated with TNF- $\alpha(10 \mathrm{ng} / \mathrm{ml})$ for 2,8 , and $24 \mathrm{~h}$. Claudin-1 protein expression was up-regulated by TNF- $\alpha$ for 8 and $24 \mathrm{~h}$.

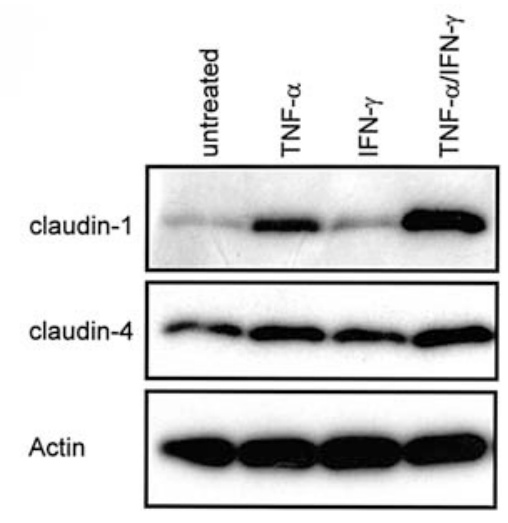

Figure 4. Expression of claudin-1 and claudin- 4 in PANC-1 cells by Western blotting. The cells were treated with TNF- $\alpha, \mathrm{IFN}-\gamma$, or TNF- $\alpha / \mathrm{IFN}-\gamma$ combination (each $50 \mathrm{ng} / \mathrm{ml}$ ) and lysed. Claudin-1 protein was up-regulated by TNF- $\alpha$ or TNF- $\alpha / \mathrm{IFN}-\gamma$ combination, while there were no significant changes in claudin-4 protein levels.

increased by TNF- $\alpha$ treatment for 2, 8, and $24 \mathrm{~h}$ (Fig. 3B). We also examined protein expression of claudin- 1 by TNF- $\alpha$. Claudin-1 was up-regulated by TNF- $\alpha$ in a concentrationdependent manner (Fig. 3C) and claudin-1 protein expression was increased by TNF- $\alpha$ for 8 and 24 h, but not 2 h (Fig. 3D).

Effects of TNF- $\alpha, I F N-\gamma$, or the TNF- $\alpha / I F N-\gamma$ combination on the expression of claudin-1 protein in PANC-1 cells. Cells were treated with $50 \mathrm{ng} / \mathrm{ml} \mathrm{TNF-} \alpha, \mathrm{IFN}-\gamma$, or TNF- $\alpha / \mathrm{IFN}-\gamma$ combination for $24 \mathrm{~h}$ and proteins were lysed. Claudin-1 protein was up-regulated by TNF- $\alpha$ or TNF- $\alpha / \mathrm{IFN}-\gamma$ combination treatment. However, there were no significant changes of claudin- 4 protein levels by the TNF- $\alpha$ or IFN- $\gamma$ treatment (Fig. 4).

Effects of knockdown of claudin-1 on proliferation and apoptosis in PANC-1 cells. To examine the role of claudin-1 in cell proliferation and apoptosis, we performed the siRNAmediated knockdown of claudin-1, and detected cleavage of PARP and cell proliferation with the Western blotting and the MTS-assay respectively. The expression of claudin-1 was down-regulated by siRNA against claudin-1 in PANC-1 cells (Fig. 5A).

Western blotting demonstrated no significant changes in cleaved PARP levels in TNF- $\alpha$-untreated cells regardless of siRNA (Fig. 5B). In contrast, siRNA against claudin-1 decreased cleaved PARP in TNF- $\alpha$-treated cells when compared with control siRNA.

MTS-assay revealed that siRNA against claudin-1 did not affect proliferation of TNF- $\alpha$-untreated cell (Fig. 6A). However, cells treated with claudin- 1 siRNA and TNF- $\alpha$ showed a $15 \%$ increase in proliferation compared to cells treated with a control siRNA $(\mathrm{p}=0.00064)$ (Fig. 6B).

\section{Discussion}

The claudins are tight junction proteins that participate in paracellular barrier and cellular connection functions $(1,2)$. Expression and function of the claudin proteins in pancreatic cancer, have not yet been extensively clarified. In this study, 
A

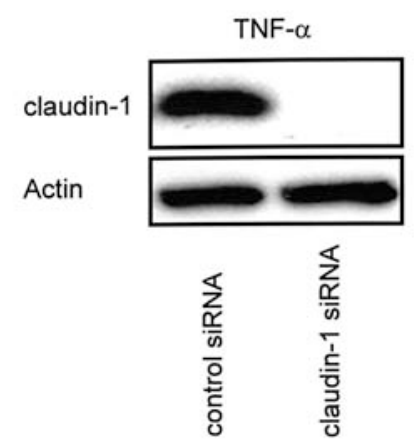

B

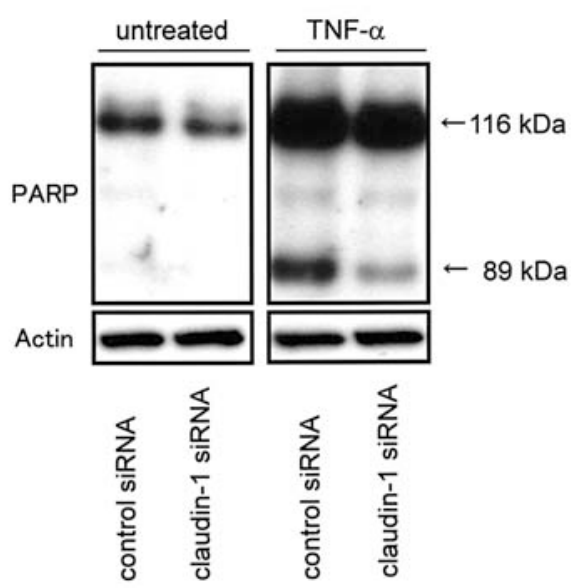

Figure 5. (A) Expression of claudin-1 in PANC-1 cells transfected siRNA against claudin- 1 by Western blotting. The cells were transfected, siRNA against claudin-1 and incubated for $48 \mathrm{~h}$. Claudin-1 expression was down-regulated by siRNA against claudin-1. (B) Detection of cleaved PARP in PANC-1 cells treated with or untreated with TNF- $\alpha$. The cells were transfected siRNA against claudin- 1 and incubated for $48 \mathrm{~h}$. Cells were treated with TNF- $\alpha$ ( 50 $\mathrm{ng} / \mathrm{ml}$ ) or untreated with TNF- $\alpha$, and incubated for $24 \mathrm{~h}$. There were no significant changes in cleaved PARP levels in TNF- $\alpha$-untreated cells. SiRNA against claudin-1 decreased cleaved PARP in TNF- $\alpha$-treated cells when compared with control siRNA.

we demonstrated the up-regulation of claudin-1 expression by TNF- $\alpha$ in a concentration-dependent manner in PANC-1 pancreatic cancer cells. In contrast, siRNA against claudin-1 increased the proliferation of PANC-1 cells treated with TNF- $\alpha$. This is the first study to determine a relationship between TNF- $\alpha$ and claudin-1 expression in the human pancreatic cancer cells.

TNF- $\alpha$ is known to bind a receptor (tumor necrosis factor receptor, TNFR) on cells to transmit signals) $(20,21)$. TNFR activation results in: a) the induction of apoptosis via activation of caspases after stimulation death domain proteins such as Fas-associated death domain (FADD) and TNFR1-associated death domain (TRADD); b) activation of nuclear factor- $\mathrm{kB}$ $(\mathrm{NF}-\kappa \mathrm{B})$; and c) activation of p38 mitogen-activated protein kinase (MAPK) (23-26). In the present study, we found that TNF- $\alpha$ induced apoptosis and inhibited cell proliferation of human pancreatic PANC-1 cancer cells. Other cytokines such as IFN- $\gamma$ did not significantly increase claudin-1 expression. Furthermore, TNF- $\alpha$ up-regulated protein levels of claudin-1, but not other claudins such as claudin-4. These results suggest
A

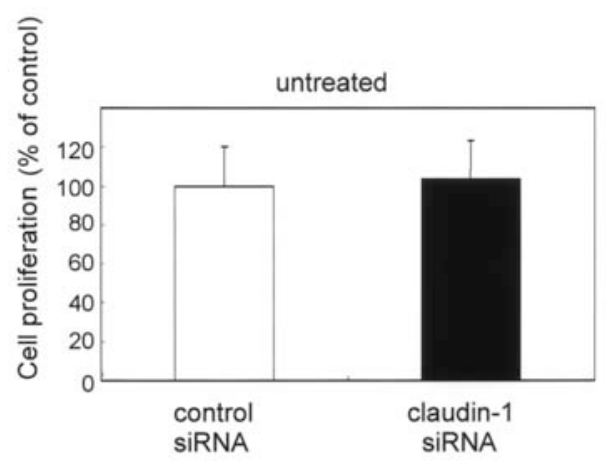

B

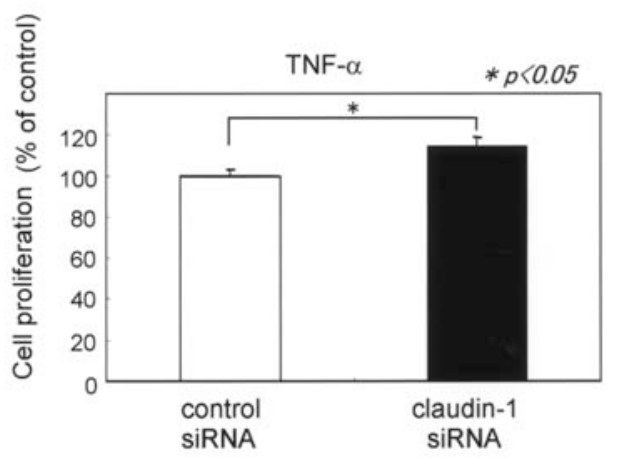

Figure 6. Proliferation of PANC-1 cells treated or untreated with TNF- $\alpha$ by MTS-assay. (A) The cells were transfected, siRNA against claudin-1 and incubated for $48 \mathrm{~h}$. SiRNA against claudin-1 did not affect proliferation of TNF- $\alpha$-untreated cells. (B) The cells were transfected, siRNA against claudin- 1 and incubated for $48 \mathrm{~h}$. After 2 days, cells were treated with TNF- $\alpha$ $(50 \mathrm{ng} / \mathrm{ml})$ and incubated for $24 \mathrm{~h}$. Cells treated with claudin-1 siRNA and TNF- $\alpha$ showed a $15 \%$ increase in proliferation compared to cells treated with control siRNA.

that claudin-1 expression is responsible for TNF- $\alpha$-dependent cell growth signals that lead to apoptosis and the inhibition of cell proliferation in pancreatic cancer cells.

In the present study, we also demonstrated that siRNA against claudin-1 affected the apoptosis and cell proliferation of PANC-1 cells. The siRNA-mediated knock-down of claudin-1 expression decreased apoptosis and inhibited stimulation of cell proliferation by TNF- $\alpha$. Several nuclear oncogenes including $c$-myc, $c$-fos and $c$-jun participate in the regulation of cell proliferation $(27,28)$. Alterations of claudin-1 expression might affect these factors. Based on the results of the present study, we speculated that claudin-1 may play an important role in the relationship between cell adhesion and TNF- $\alpha$-dependent growth signals in pancreatic cancer cells. However, this hypothesis has not yet been tested. In the near future, we plan to clarify the mechanisms and significance of claudin-1 in apoptosis and cell proliferation of human cancer cells.

\section{Acknowledgements}

This work was supported by Grants in Aid for Science from the Ministry of Education, Culture, Sports, Science and Technology of Japan. 


\section{References}

1. Tsukita S, Furuse $M$ and Itoh $M$ : Structural and signalling molecules come together at tight junctions. Curr Opin Cell Biol 11: 628-633, 1999.

2. Tsukita S, Furuse M and Itoh M: Multifunctional strands in tight junctions. Nat Rev Mol Cell Biol 2: 285-293, 2001.

3. Furuse M, Fujita K, Hiiragi T, Fujimoto K and Tsukita S: Claudin-1 and -2 : novel integral membrane proteins localizing at tight junctions with no sequence similarity to occludin. J Cell Biol 141: 1539-1550, 1998 .

4. Tsukita $\mathrm{S}$ and Furuse M: Occludin and claudins in tight-junction strands: leading or supporting players? Trends Cell Biol 9: 268-273, 1999.

5. Ivanov AI, Nusrat A and Parkos CA: Endocytosis of epithelial apical junctional proteins by a clathrin-mediated pathway into a unique storage compartment. Mol Biol Cell 15: 176-188, 2004.

6. Morohashi S, Kusumi T, Sato F, Odagiri H, Chiba H, Yoshihara S, Hakamada K, Sasaki M and Kijima H: Decreased expression of claudin-1 correlates with recurrence status in breast cancer. Int J Mol Med 20: 139-143, 2007.

7. Kominsky SL, Argani P, Korz D, Evron E, Raman V, Garrett E, Rein A, Sauter G, Kallioniemi OP and Sukumar S: Loss of the tight junction protein claudin-7 correlates with histological grade in both ductal carcinoma in situ and invasive ductal carcinoma of the breast. Oncogene 22: 2021-2033, 2003.

8. Krämer F, White K, Kubbies M, Swisshelm K and Weber BH: Genomic organization of claudin-1 and its assessment in hereditary and sporadic breast cancer. Hum Genet 107: 249-256, 2000 .

9. Miwa N, Furuse M, Tsukita S, Niikawa N, Nakamura Y and Furukawa Y: Involvement of claudin-1 in the beta-catenin/Tcf signaling pathway and its frequent upregulation in human colorectal cancers. Oncol Res 12: 469-476, 2001.

10. Hough CD, Sherman-Baust CA, Pizer ES, Montz FJ, Im DD, Rosenshein NB, Cho KR, Riggins GJ and Morin PJ: Large-scale serial analysis of gene expression reveals genes differentially expressed in ovarian cancer. Cancer Res 60: 6281-6287, 2000.

11. Sawada N, Murata M, Kikuchi K, Osanai M, Tobioka H, Kojima $\mathrm{T}$ and Chiba $\mathrm{H}$ : Tight junctions and human diseases. Med Electron Microsc 36: 147-156, 2003.

12. Hirohashi S and Kanai Y: Cell adhesion system and human cancer morphogenesis. Cancer Sci 94: 575-581, 2003.

13. Fazal S and Saif MW: Supportive and palliative care of pancreatic cancer. JOP 8: 240-253, 2007.

14. Korc M: Role of growth factors in pancreatic cancer. Surg Oncol Clin N Am 7: 25-41, 1998.

15. Lideståhl A, Permert J, Linder S, Bylund H, Edsborg N and Lind P: Efficacy of systemic therapy in advanced pancreatic carcinoma. Acta Oncol 45: 136-143, 2006.

16. Welsch T, Kleeff $\mathrm{J}$ and Friess $\mathrm{H}$ : Molecular pathogenesis of pancreatic cancer: advances and challenges. Curr Mol Med 7: 504-521, 2007.
17. Yeh JJ and Der CJ: Targeting signal transduction in pancreatic cancer treatment. Expert Opin Ther Targets 11: 673-694, 2007.

18. Kijima H, Yamazaki H, Nakamura M, Scanlon KJ, Osamura RY and Ueyama Y: Ribozyme against mutant K-ras mRNA suppresses tumor growth of pancreatic cancer. Int J Oncol 24: 559-564, 2004.

19. Tsuchida T, Kijima H, Hori S, Oshika Y, Tokunaga T, Kawai K, Yamazaki H, Ueyama Y, Scanlon KJ, Tamaoki N and Nakamura M: Adenovirus-mediated anti-K-ras ribozyme induces apoptosis and growth suppression of human pancreatic carcinoma. Cancer Gene Ther 7: 373-383, 2000.

20. Sato T, Yamauchi N, Sasaki H, Takahashi M, Okamoto T, Sakamaki S, Watanabe N and Niitsu Y: An apoptosis-inducing gene therapy for pancreatic cancer with a combination of $55-\mathrm{kDa}$ tumor necrosis factor (TNF) receptor gene transfection and mutein TNF administration. Cancer Res 58: 1677-1683, 1998.

21. Stephens LA, Thomas HE, Ming L, Grell M, Darwiche R, Volodin L and Kay TW: Tumor necrosis factor- $\alpha$-activated cell death pathways in NIT-1 insulinoma cells and primary pancreatic beta cells. Endocrinology 140: 3219-3227, 1999.

22. Kuninaka S, Yano T, Yokoyama H, Fukuyama Y, Terazaki Y, Uehara T, Kanematsu T, Asoh $\mathrm{H}$ and Ichinose $\mathrm{Y}$ : Direct influences of pro-inflammatory cytokines (IL-1 $\beta$, TNF- $\alpha$ and IL-6) on the proliferation and cell-surface antigen expression of cancer cells. Cytokine 12: 8-11, 2000

23. Baker SJ and Reddy EP: Modulation of life and death by the TNF receptor superfamily. Oncogene 17: 3261-3270, 1998.

24. Bradham CA, Qian T, Streetz K, Trautwein C, Brenner DA and Lemasters JJ: The mitochondrial permeability transition is required for tumor necrosis factor $\alpha$-mediated apoptosis and cytochrome c release. Mol Cell Biol 18: 6353-6364, 1998

25. Ozes ON, Mayo LD, Gustin JA, Pfeffer SR, Pfeffer LM and Donner DB: NF-kappaB activation by tumour necrosis factor requires the Akt serine-threonine kinase. Nature 401: 82-85, 1999.

26. Craig R, Larkin A, Mingo AM, Thuerauf DJ, Andrews C McDonough PM and Glembotski CC: p38 MAPK and NFkappa B collaborate to induce interleukin- 6 gene expression and release. Evidence for a cytoprotective autocrine signaling pathway in a cardiac myocyte model system. J Biol Chem 275: 23814-23824, 2000.

27. Law BK, Waltner-Law ME, Entingh AJ, Chytil A, Aakre ME, Norgaard P and Moses HL: Salicylate-induced growth arrest is associated with inhibition of p70s6k and down-regulation of cmyc, cyclin D1, cyclin A and proliferating cell nuclear antigen. J Biol Chem 275: 38261-38267, 2000.

28. Maeno K, Masuda A, Yanagisawa K, Konishi H, Osada H, Saito T, Ueda $\mathrm{R}$ and Takahashi T: Altered regulation of c-jun and its involvement in anchorage-independent growth of human lung cancers. Oncogene 25: 271-277, 2006. 